\title{
ON SOME GEOCHEMICAL FEATURES IN THE BLACK SCHISTS OF THE OUTOKUMPU AREA, FINLAND
}

\author{
Esko Peltola \\ Outokumpu Company, Outokumpu, Finland
}

\begin{abstract}
The paper deals with some elements characteristic of carbonaceous schists. The mutual relationship of these elements and their distribution in schist fractions were studied in order to shed light on the depositional conditions of the Precambrian black schists in the Outokumpu region, East Finland. Special attention is paid to the variation in the carbon to sulphur weight per cent ratio and to the concentration of $\mathrm{B}$ and $\mathrm{V}_{2} \mathrm{O}_{5}$. The results are compared with those obtained from contemporaneous and younger through to recent carbonaceous formations, about the origin of which more information is available.
\end{abstract}

\section{CONTENTS}

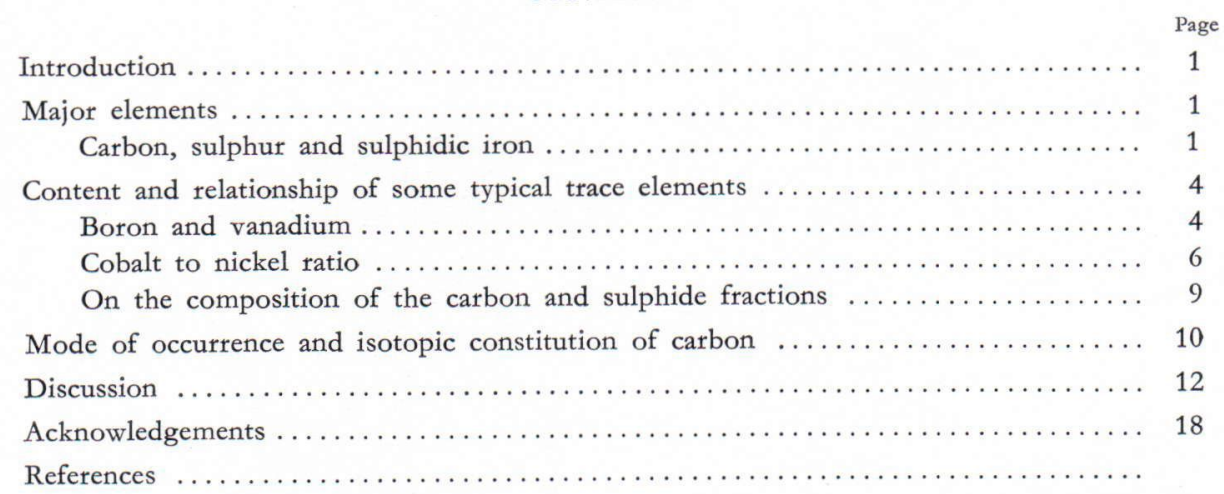

\section{Introduction}

It is a well known fact that the composition of carbonaceous schists is greatly dependent on factors relating to the primary sedimentation, i.e. on the depositional environment. The comparison of carbonaceous schists formed under different conditions has further revealed that in addition to major constituents, some trace elements are also characteristic of certain depositional conditions. In addition to the bulk analyses, studies on the composition of the various fractions of these rocks have also recently gained favour. Thus, e.g. the trace element contents in the carbonaceous schists and sulphide fractions separated from the schists have turned out to be significant to the environmental studies of the marine and freshwater sediments. 

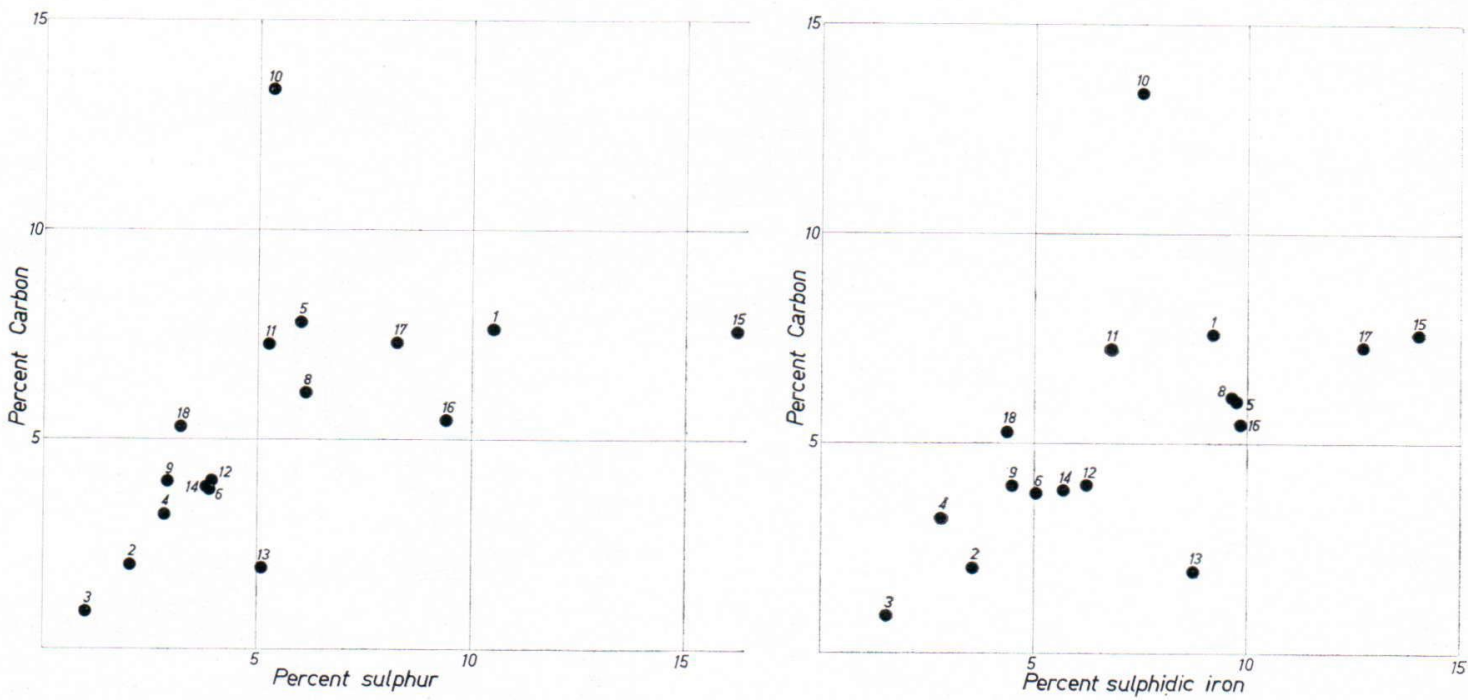

Fig. 1. Carbon-sulphur and carbon-sulphidic iron weight per cent relations in the black schists of the Outokumpu region. The numbers refer to the analyses in Table 1 .

The studies dealing with the origin of the carbonaceous formations are mainly based on the recent sediments and the younger less metamorphic schists. In the following, some chemical relations existing in the black schists in East Finland are considered. The findings are compared with those obtained from other contemporaneous and younger formations thus augmenting the information concerning the geologic history of the Precambrian metasapropelites.

\section{Major elements}

\section{Carbon, sulphur and sulpbidic iron}

While considering the origin of the black schists in the Outokumpu region on the basis of their mode of occurrence and chemical composition, the present author (Peltola, 1960) paid attention to the variation in their carbon and sulphur content. Although the relative amounts of sulphides (mainly pyrite and pyrrhotite) vary, the sulphide content increases parallel to that of carbon (Fig. 1). This is most conspicuous in the argillaceous black schist variants which are

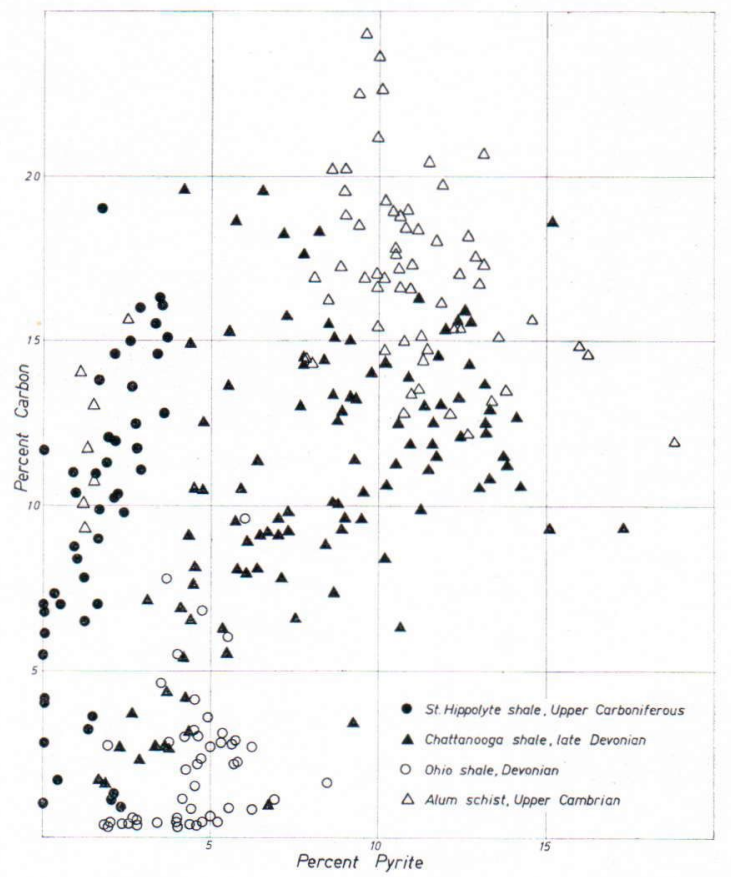

Fig. 2. Carbon-pyrite weight per cent relations in the carbonaceous shales and schists of different ages and depositional conditions (According to Strahl).

common in North Karelia, East Finland. Usually the amount of sulphides is higher in the 
calcareous black schist varieties. The carbon and sulphur content ranges from a few per cent to $10-15$ per cent, both varying within the same limits. Dr. T. A. Häkli kindly computed the standard deviations and the coefficients of correlations: $\mathrm{r} \mathrm{Fe}-\mathrm{C}, \mathrm{r} \mathrm{Fe}-\mathrm{S}$ and $\mathrm{r} \mathrm{C}-\mathrm{s}$ for carbon, sulphur and sulphidic iron listed in Table 1.

$\mathrm{r}_{\mathrm{Fe}-\mathrm{C}}=0.499$; correlation is significant at the 0.05 level $\mathrm{r}_{\mathrm{Fe}-\mathrm{S}}=0.845 ; "$; $"$ " $" 0.01$ 》

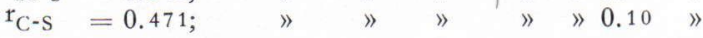

Similar observations have also been made on the younger weakly metamorphosed carbonaceous schists from whose depositional conditions more information is available than from the bedrock area, due to geologic and geochemical investigations. Fig. 2, which is based on the studies of Strahl (1958) concerning the Upper Carboniferous shale of St. Hippolyte in France, the late Devonian Chattanooga shale in Tennessee, the Devonian shales in Ohio and the Upper Cambrian alum shales in Sweden, shows the variation in carbon and pyrite in the schists of these areas. According to Strahl »the results of the analysis of the Chattanooga, Ohio and Alum shales show many of the features accepted as characteristic of the reducing marine environment. The decrease in the amount of organic carbon and the associated constituents pyrite and uranium indicates that the Ohio shale was deposited at a more rapid rate than the Chattanooga and Alum shales. The character of the St. Hippolyte shale is distinctly different and shows, that this shale is of continental rather than of marine origin. The relative deficiency in pyrite and the abundance of siderite and iron oxides indicates a somewhat more oxidative environment too».

As indicated by Fig. 2, there are differences in the variation of the pyrite and carbon contents in the schists. It may not be chance that the St. Hippolyte shale, which Strahl considers as nonmarine in origin, shows a relative deficiency in pyrite, whereas the marine shales contain pyrite more abundantly and the amounts of carbon and pyrite fluctuate within the same limits.
According to Murty et al (1962), the organic carbon content of the Precambrian black shales, exposed at Nagarjunasagar, India, has a fairly direct relationship to the content of sulphur and ferrous iron in the sulphide. The black shales are siliceous in composition and their organic carbon and sulphur contents are low resembling the aranaceous schist variety in the Outokumpu region.

Studies on recent carbonaceous sediments have also revealed that under marine conditions with sulphate abundantly available, more sulphides are formed than in fresh-water basins of similar environments. This conclusion is supported, according to Keith and Byström (1959) and Degens et al (1959), by sulphur analyses of marine and fresh-water shales of Pennsylvanian age as well as of modern fresh-water and marine muds from Oahu, Hawaii.

Strakhov (1960) found out that in the highly reducing marine environments, sulphides are formed in amounts comparable with those of carbon. While considering the composition of the euxinic sediments in the Black Sea, he states that the irregular distribution of pyrite almost exactly parallels the distribution of organic carbon, both of which increase markedly in the centre of the sedimentation basin.

Strakhov et al (1959) have developed a quantitative geochemical method for the analysis of sedimentary strata in order to determine the conditions of their formation. According to them, sin the rocks of marine origin the ratio of pyritic iron to residual organic carbon fluctuates between 0.2 and 2.0, but i.n the majority of cases it is betwwen 0.5 and 0.8 . In the rocks of continental origin these ratios are between 0.03 and 0.06 and in the deposits formed in intermediate environments (in lagoons) these ratios occupy an intermediate position varying between 0.06 and 0.2 . The ratio of pyrite iron to residual organic carbor in rocks formed in the same environment varies somewhat from region to region, but the general tendency of a sharp increase in this ratio in the transition from continerital to sea rocks 
has been established for many coal basins of the »USSR».

In the highly metamorphosed Precambrian black schists of the Outokumpu area the ratio varies from 0.6 to 1.8 , with an average of 1.3 (Fig. 1) thus clearly indicating a marine depositional environment. In some calcareous black schist varieties with higher amounts of sulphides the ratio may rise up to 4.5 . The local abundance of sulphides in the skarn-predominant schists of this type can partly be attributed to the mobilisation of the sulphidic matter during regional metamorphism.

\section{Content and relationship of some typical trace elements}

\section{Boron and vanadium}

The analyses of the Precambrian carbonaceous schists in North Karelia show a regular boron content which varies between 0.001 and $0.1 \% \mathrm{~B}$. In black schist, the boron content is higher than in the other rocks of the area in general,i.e. in the quartzites and micaceous schists. The average boron tenor in the 18 analysed black schist samles was $0.015 \%$ B (Table 1). This is approximately the same as that obtained by Th.G. Sahama (1945) for the Precambrian black schists of South Lapland $\left(0.006-0.1 \% \mathrm{~B}_{2} \mathrm{O}_{3}\right)$ and as that reported by S. Landergren (1945) for the Cambrian alum shales in Sweden (0.009$0.014 \%$ B). In the mica schists and quartzites of the Outokumpu area the boron content fluctuates from 0.001 to $0.008 \% \mathrm{~B}$.

Areal comparison of the boron abundances indicates that the phyllites and black schists in the eastern part of the area and in Mulo, south of Joensuu, are richest in boron, the abundance varying between 0.008 and $0.1 \% \mathrm{~B}$. The boron tenor decreases westwards and the lowest values are encountered at Outokumpu and Luikonlahti.

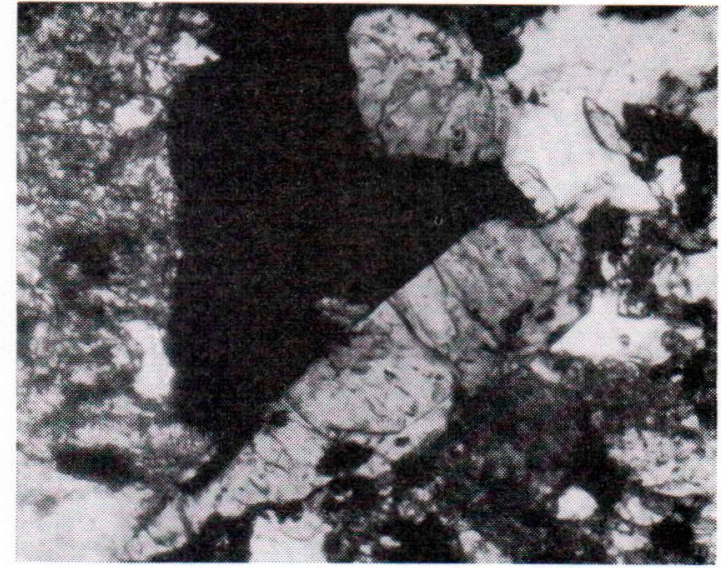

Fig. 3. Tourmaline porphyroblast in sulphide-rich black schist. Outokumpu mine. One Nicol. Magnification $500 \mathrm{x}$.

The highest concentrations of boron are met with outside the serpentinite area (Table 1, Nos. $1,2,3,4,12$ and 19), whereas in the vicinity of the largest serpentinite bodies the boroti content in the black schists remains below the average value $(0.015 \%$ B) although the serpentinites also have a moderate boron tenor. The average boron content, obtained from a dozen serpentinite samples, is about $0.005 \% \mathrm{~B}$.

The carrier of boron has been investigated. In some thin sections, tourmaline grains have been observed with optical properties compatible with those of chromian tourmaline. They occur in the carbon-rich portions of the schist as small (0.1 $0.2 \mathrm{~mm}$ in diameter) but euhedral crystals (Fig. 3). No rounded detrital grains have been observed. It is well motivated to suppose that boron originates from the marine depositional environments of the original sediment, for boron is a biophile and definitely thalassophile element. Tourmaline is a common carrier of boron in all rocks of marine sedimentogenic origitr.

Vat.adium, a typical biophile element, is encountered in the black schists in amounts differing from those in the other schists of the area and varying from 0.04 to $0.23 \% \mathrm{~V}_{2} \mathrm{O}_{5}$ with an average of $0.11 \% \mathrm{~V}_{2} \mathrm{O}_{5}$ (Table 1). According to the previous work of the present author (Peltola, 
Table 1

Abundances of some charaeteristic elements in various carbon-

\begin{tabular}{|c|c|c|}
\hline $\begin{array}{l}\text { Sample } \\
\text { N:o }\end{array}$ & Rock type & Location \\
\hline $\begin{array}{r}1 \\
2 \\
3 \\
4 \\
5 \\
6 \\
7 \\
8 \\
9 \\
10 \\
11\end{array}$ & 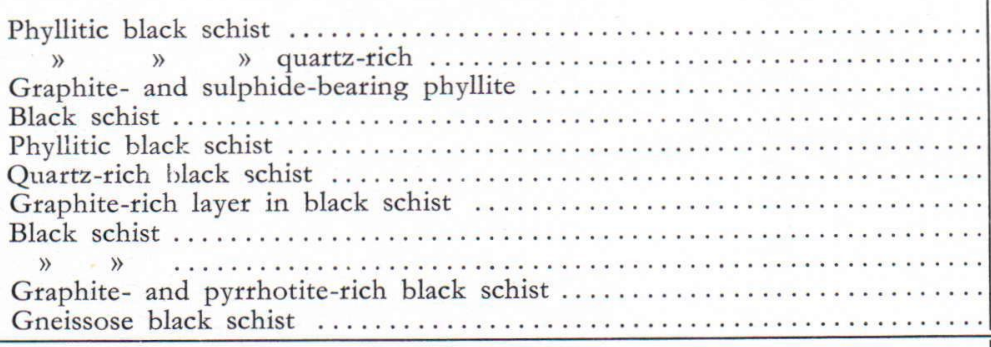 & $\begin{array}{l}\text { Lake Höytiäinen, Polvijärvi } \\
\text { " " } \\
\text { Käsämä, } \\
\text { Solansaari, } \\
\text { Suopolvi, } \\
\text { Viitalampi, } \\
\text { Mertala, } \\
\text { Sukkulansalo, Kuusjärvi .. } \\
\text { Outokumpu mine, 285-level } \\
\text { " } \\
\text { Luikonlahti, Kaavi ....... }\end{array}$ \\
\hline $\begin{array}{l}12 \\
13 \\
14 \\
15 \\
16 \\
17 \\
18\end{array}$ & 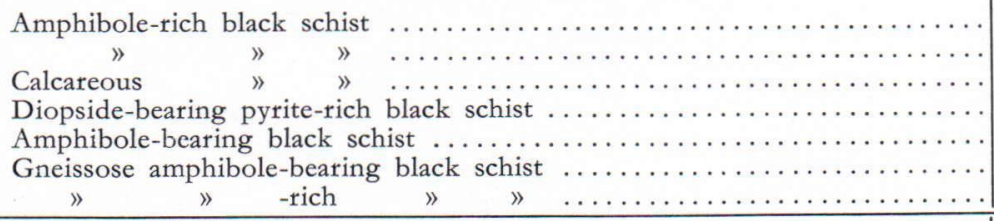 & $\begin{array}{l}\text { Mulo, Pyhäselkä } \\
\text { Sukkulansalo, Kuusjärvi } \\
\text { Matovaara, Outokumpu } \\
\text { Outokumpu mine, 320-level } \\
\text { Ulla, Kuusjärvi } \\
\text { Itkonsalo" " } \\
\text { Luikonlahti, Kaavi }\end{array}$ \\
\hline & 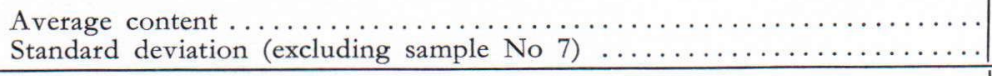 & \\
\hline $\begin{array}{l}19 \\
20 \\
21 \\
22 \\
23 \\
24\end{array}$ & 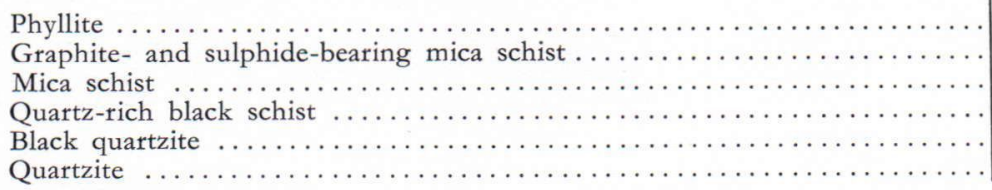 & $\begin{array}{l}\text { Kinahmo, Polvijärvi } \\
\text { Kupinpuro » } \\
\text { Keretti shaft, Outokumpu } \\
\text { Kyykeri „ } \\
\text { Outokumpu mine, 285-level } \\
\text { Outokumpu mine, 285-level }\end{array}$ \\
\hline
\end{tabular}

1960), the consistency between the vanadium content and the organic matter cannot always be perceived in the black schists of the Outokumpu region. However, it is roughly valid for the varieties of schists richest in carbon and for the carbon-poor mica schists and quartzites. In certain layers extremely rich is carbon and aluminium, the vanadium content is higher than $0.20 \%$ $\mathrm{V}_{2} \mathrm{O}_{5}$. The contents determined in the phyllites, mica schists and quartzites are considerably lower and from 0.02 to $0.05 \% \mathrm{~V}_{2} \mathrm{O}_{5}$.

According to Goldschmidt (1954), the vanadium content in marine shales is higher than in corresponding fresh-water deposits. Degetis et al (1957) state, however, that this is valid only as far as the carbon fractions of these deposits are concerned. The abundance of vanadium in the black schists of the Outokumpu region is of the same order of magnitude as that in several marine carbonaceous deposits of different ages and known origin.

\section{Cobalt to nickel ratio}

The abundance of tiickel in the black schists of the area fluctuates from 0.013 to $0.221 \%$ with an average of $0.051 \% \mathrm{Ni}$. The corresponding figures for cobalt are $0.004-0.020 \%$ and $0.0076 \%$ Co, respectively. The highest values are encountered in argillaceous black schist varieties. Some of the Ni and Co values obtained from phyllites and mica schists are lower than the average $\mathrm{Ni}$ and $\mathrm{Co}$ values for black schists (Table 1). In the following, attention is paid to the mutual relationship between the cobalt and 
and sulphide-bearing schists of the Outokumpu region

\begin{tabular}{|c|c|c|c|c|c|c|c|c|c|}
\hline \multicolumn{10}{|c|}{$\%$} \\
\hline B & $\mathrm{V}_{2} \mathrm{O}_{5}$ & $\mathrm{Ni}$ & Co & $\mathrm{Co} / \mathrm{Ni}$ & $\mathrm{Fe}(\mathrm{S})$ & C & S & $\mathrm{Fe}(\mathrm{S}) / \mathrm{C}$ & \\
\hline 0.100 & 0.20 & 0.022 & 0.0042 & 0.19 & 9.19 & 7.62 & 10.48 & 1.2 & \\
\hline 0.075 & 0.11 & 0.013 & 0.0060 & 0.46 & 3.56 & 2.03 & 2.04 & 1.7 & \\
\hline 0.025 & 0.04 & 0.221 & 0.0170 & 0.08 & 1.55 & 0.91 & 1.00 & 1.7 & U్ \\
\hline 0.015 & 0.11 & 0.026 & 0.0140 & 0.54 & 2.83 & 3.22 & 2.83 & 0.9 & ש \\
\hline 0.002 & 0.11 & 0.085 & 0.0068 & 0.08 & 9.75 & 6.00 & 7.80 & 1.6 & 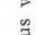 \\
\hline 0.003 & 0.06 & 0.116 & 0.0092 & 0.08 & 5.05 & 3.82 & 3.90 & 1.3 & อี \\
\hline 0.010 & 0.04 & 0.040 & 0.0200 & 0.50 & 2.33 & 28.42 & 1.45 & 0.1 & $\stackrel{\check{U}}{=}$ \\
\hline 0.010 & 0.09 & 0.028 & 0.0042 & 0.15 & 9.65 & 6.08 & 6.10 & 1.6 & $\overline{50}$ \\
\hline$<0.001$ & 0.09 & 0.029 & 0.0043 & 0.15 & 4.50 & 4.00 & 2.90 & 1.1 & \\
\hline$<0.001$ & 0.23 & 0.083 & 0.0100 & 0.12 & 7.52 & 13.36 & 5.32 & 0.6 & \\
\hline 0.002 & 0.10 & 0.035 & 0.0060 & 0.17 & 6.80 & 7.26 & 5.26 & 0.9 & \\
\hline 0.025 & 0.14 & 0.025 & 0.0037 & 0.15 & 6.23 & 4.01 & 3.93 & 1.6 & $\stackrel{\mathscr{H}}{*}$ \\
\hline$<0.001$ & 0.13 & 0.027 & 0.0057 & 0.21 & 8.75 & 1.96 & 5.10 & 4.5 & . \\
\hline 0.002 & 0.18 & 0.025 & 0.0036 & 0.14 & 5.68 & 3.88 & 3.80 & 1.5 & 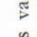 \\
\hline 0.001 & 0.15 & 0.036 & 0.0047 & 0.13 & 14.03 & 7.60 & 16.20 & 1.8 & $\tilde{0}$ \\
\hline 0.002 & 0.08 & 0.057 & 0.0072 & 0.13 & 9.86 & 5.45 & 9.40 & 1.8 & हुँ \\
\hline$<0.001$ & 0.06 & 0.032 & 0.0061 & 0.19 & 12.72 & 7.29 & 8.23 & 1.7 & $\frac{\tilde{U}}{\tilde{J}}$ \\
\hline$<0.001$ & 0.06 & 0.017 & 0.0040 & 0.23 & 4.36 & 5.28 & 3.20 & 0.8 & \\
\hline 0.015 & 0.11 & 0.051 & 0.0076 & 0.15 & $\begin{array}{l}7.18 \\
3.45\end{array}$ & $\begin{array}{l}5.28 \\
3.01\end{array}$ & $\begin{array}{l}5.73 \\
3.76\end{array}$ & 1.3 & \\
\hline 0.008 & 0.05 & 0.008 & 0.0056 & 0.70 & 1.08 & 0.44 & 0.71 & 1.5 & $\stackrel{\mathscr{g}}{\tilde{g}}$ \\
\hline 0.001 & 0.01 & 0.007 & 0.0035 & 0.50 & 1.12 & 1. 49 & 0.70 & 0.8 & हू है \\
\hline 0.003 & 0.04 & 0.009 & 0.0065 & 0.72 & 1.70 & 0.66 & 1.10 & 1.5 & $\dot{\square}$ \\
\hline 0.001 & 0.06 & 0.018 & 0.0080 & 0.44 & 2.67 & 1.96 & 1.66 & 1.4 & छ \\
\hline$<0.001$ & 0.04 & 0.170 & 0.0077 & 0.04 & 2.25 & 0.37 & 1.83 & 6.1 & 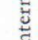 \\
\hline 0.001 & 0.02 & 0.009 & 0.0040 & 0.44 & 0.51 & 0.04 & 0.33 & 15.4 & \\
\hline
\end{tabular}

nickel tenors, which, according to some authors, is of importance when determining the origin of deposits.

The average cobalt to nickel ratio in eighteen black schist specimens is 0.15 . In some sulphide fractions separated from black schists this ratio is 0.13 (See Table 2).

Marmo (1960) has investigated minor element contents in sulphide and graphite schists from various parts of Finland and has found that the abundance of nickel invariably (61 determinations) exceeds that of cobalt (40 determinations). The average nickel and cobalt content is $0.058 \%$ and $0.011 \%$, respectively. The cobalt to nickel ratio is 0.19 , which is approximately the same as that in the Outokumpu area. Further, according, to Marmo, the corresponding ratio in the pyrrhotite fraction of these same schists (over 20 determinations) is 0.17 , although the abundances of nickel
$(0.084 \%)$ and cobalt $(0.014 \%)$ are somewhat higher than in the host rock.

Landergren (1948) confirmed that the cobalt to nickel ratio in the Cambrian alum shales in Sweden is $0.05(0.02 \%$ Co and $0.4 \% \mathrm{Ni})$. The carbonaceous shales in Sweden contain about $0.01-0.04 \%$ nickel, the cobalt being less than a tenth of these values, as reported by Westergårdh (1944).

In the Romanian gyttja and sapropel sediments and in the German copper shales the abundance of nickel fluctuates from $0.009 \%$ to $0.04 \%$ and that of cobalt from $0.003 \%$ to $0.007 \%$ (Goldschmidt, 1937 a). Janda and Schroll (1959) have observed that in some of the graphite fractions extracted from the bituminous shales in Germany the abundance of nickel fluctuates between 18 and $100 \mathrm{~g} / \mathrm{t}$ and that of cobalt between nil and $0.90 \mathrm{~g} / \mathrm{t}$, the average cobalt to nickel ratio 
TABLE 2

Distribution of some characteristic trace-elements in some black schist specimens in the Outokumpu region

\begin{tabular}{|c|c|c|c|c|c|c|c|c|c|c|}
\hline \multirow{2}{*}{$\begin{array}{l}\text { Sample } \\
\text { N:o }\end{array}$} & & \multicolumn{8}{|c|}{$\%$} & \multirow{2}{*}{$\frac{\mathrm{ppm}}{\mathrm{U}_{3} \mathrm{O}_{8}}$} \\
\hline & & $\mathrm{Cu}$ & $\mathrm{Zn}$ & $\mathrm{Ni}$ & Co & Mo & As & $\mathrm{Pb}$ & $\mathrm{V}_{2} \mathrm{O}_{5}$ & \\
\hline \multirow{3}{*}{1} & Bulk composition & 0.018 & 0.05 & 0.063 & 0.007 & 0.010 & 0.029 & 0.005 & 0.15 & 24 \\
\hline & Sulphide fraction . & 0.015 & 0.15 & 0.120 & 0.025 & 0.002 & 0.070 & 0.002 & 一 & 16 \\
\hline & Carbon & 0.030 & 0.05 & 0.070 & 0.001 & 0.032 & 0.019 & 0.010 & 0.13 & 12 \\
\hline
\end{tabular}

\begin{tabular}{|c|c|c|c|c|c|c|c|c|c|c|c|}
\hline \multirow{3}{*}{2} & Bulk composition & & 0.015 & 0.01 & 0.025 & 0.002 & 0.007 & 0.005 & 0.004 & 0.14 & 40 \\
\hline & Sulphide fraction & 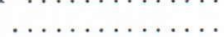 & 0.070 & 0.07 & 0.220 & 0.030 & 0.003 & 0.012 & 0.003 & 0.02 & 200 \\
\hline & Carbon " & $\ldots \ldots \ldots \ldots$ & 0.070 & 0.01 & 0.015 & $<0.001$ & 0.007 & 0.010 & 0.007 & 0.14 & 100 \\
\hline
\end{tabular}

\begin{tabular}{|c|c|c|c|c|c|c|c|c|c|c|c|}
\hline \multirow{3}{*}{3} & Bulk composition & & 0.025 & 0.03 & 0.025 & 0.002 & 0.007 & 0.004 & 0.003 & 0.14 & 40 \\
\hline & Sulphide fraction & & 0.100 & 0.50 & 0.270 & 0.030 & 0.003 & 0.012 & 0.005 & 0.01 & 40 \\
\hline & Carbon $\quad »$ & . & 0.065 & 0.03 & 0.015 & $<0.001$ & $<0.010$ & 0.005 & 0.012 & 0.11 & 200 \\
\hline
\end{tabular}

\begin{tabular}{|c|c|c|c|c|c|c|c|c|c|c|c|}
\hline 4 & $\begin{array}{l}\text { Bulk composition } \\
\text { Sulphide fraction } \\
\text { Carbon }\end{array}$ & 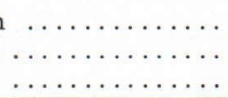 & $\begin{array}{l}0.025 \\
0.200 \\
0.072\end{array}$ & $\begin{array}{l}0.03 \\
0.30 \\
0.03\end{array}$ & $\begin{array}{l}0.025 \\
0.230 \\
0.016\end{array}$ & $\begin{array}{r}0.002 \\
0.030 \\
<0.001\end{array}$ & $\begin{array}{l}0.007 \\
0.003 \\
0.006\end{array}$ & $\begin{array}{r}0.005 \\
0.013 \\
-\end{array}$ & $\begin{array}{l}0.003 \\
0.005 \\
0.010\end{array}$ & $\begin{array}{l}0.21 \\
0.03 \\
0.044\end{array}$ & $\begin{array}{r}40 \\
40 \\
150\end{array}$ \\
\hline 5 & $\begin{array}{l}\text { Bulk composition } \\
\text { Sulphide fraction } \\
\text { Carbon }\end{array}$ & $\begin{array}{c}\ldots \ldots \ldots \ldots \ldots \\
\ldots \ldots \ldots \ldots \ldots m \\
\ldots \ldots \ldots m \ldots\end{array}$ & $\begin{array}{l}0.015 \\
0.070 \\
0.080\end{array}$ & $\begin{array}{l}0.02 \\
0.20 \\
0.04\end{array}$ & $\begin{array}{l}0.025 \\
0.280 \\
0.025\end{array}$ & $\begin{array}{l}0.002 \\
0.030 \\
0.001\end{array}$ & $\begin{array}{l}0.007 \\
0.003 \\
0.030 \\
\end{array}$ & $\begin{array}{l}0.004 \\
0.006 \\
0.005\end{array}$ & $\begin{array}{l}0.002 \\
0.003 \\
0.015\end{array}$ & $\begin{array}{l}0.14 \\
0.01 \\
0.32\end{array}$ & $\begin{array}{r}40 \\
40 \\
150 \\
\end{array}$ \\
\hline
\end{tabular}

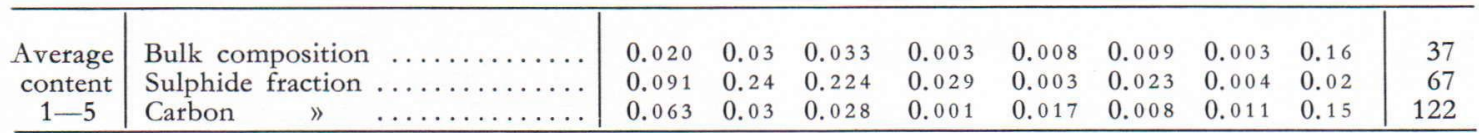

1. Graphite- and pyrite-rich black schist, Outokumpu mine, 320 level.

2. Argillaceous black schist, Sukkulansalo (drill core Oku 141, between 88.7 and 96.0 m), Kuusjärvi.

3. Amphibole-bearing black schist, Sukkulansalo (drill core Oku 141, between 130.9 and 137.5 m), Kuusjärvi.

4. Argillaceous black schist, Sukkulansalo (drill core Oku 142, between 73.5 and 77.3 m), Kuusjärvi.

5. Gneissose amphibole-bearing black schist, Sukkulansalo (drill core Oku 143, between 91.1 and $94.5 \mathrm{~m}$ ) Kuusjärvi.

being 0.6. According to Hegemann (1943), the cobalt to nickel ratio is more or less constant and about $0.05(0.02 \% \mathrm{Ni}$ and $0.001 \% \mathrm{Co})$ in sedimentogeneous pyrites.

Strakhov (1960) has demonstrated that this ratio varies in the Black Sea sediments from 0.18 to 0.68 the lowest value being in clay muds and the highest in shell sands.

The nickel and boron contents should be critically reviewed on account of the abundant occurrence of serpentinite containing moderate amounts of both of these elements. Accordingly, sets of samples were taken across some contact zones of the serpentinites. It was found out that the alteration zone usually existing between black schist and serpentinite was enriched in $\mathrm{Cu}$, $\mathrm{Zn}, \mathrm{Ni}, \mathrm{Cr}$ and $\mathrm{B}$. The borders of the alteration zone (the transition series is as follows: black schist-biotite-chlorite- talc-bearing tremolite-serpentinite) as well as the portions of the black schist and serpentinite closest to it were impoverished in these elements for a distance of a few decimetres or at most a couple of metres. Further away from the contact the abundances are more constant and fluctuate within the limits characteristic of both wall rocks. This same phe- 
nomenon can be observed in the alteration zone between quartzite and serpentinite (the succession is as follows: quartzite- diopside skarn-tremolite skarn- dolomite- serpentinite) although the influence of serpentinite, especially on the abundance of chromium and nickel, extends further away from the contact, obviously due to the higher permeability of the quartzitic rock.

\section{On the composition of the carbon and sulphide fractions}

Carbon and sulphide fractions were separated from some black schist samples typical of the Outokumpu zone in the Research Laboratory of Exploration. The fraction s as well as the schist samples were analysed for trace elements (Table 2). The separation of the fractious was performed in such a way that first of all the samples were ground under 200 mesh. The material was then treated on a concentrating table and the lightest fraction reground down to 400 mesh. The carbon fraction was separated by means of a bromoform alcohol liquid with a density of $2.55 \mathrm{~g} / \mathrm{cm}^{3}$. The material was centrifuged three times. The heavy minerals were extracted with the aid of a concentrating table and heavy liquids.

Comparison of the concentrations in the schist fractions shows that copper, zinc, nickel, cobalt and arsene are enriched in the sulphide fraction as was anticipated. The sulphides of the above elements (excluding arsene) are frequently encountered in all black schists. Nickel is incorporated in pe-tlandite, which occurs in pyrrhotite as exsolution lamellae or grains. On the basis of the optical properties some grains were identified as cobalt pentlandite. Copper occurs as chalcopyrite and zinc as sphalerite.

From among the elements enriched in the carbor fraction of the black schist mentio may be made of molybdenium, lead, uranium and vanadium. Also the abundance of copper has increased. According to the previous studies of the present author (Peltola, 1960), part of the lead is of radiogenic origin occurring as inclu- sions within uraninite grains in the schists. The uraninite grains are enveloped by a thick carbonaceous shell. On account of this shell, uranium and partly also lead are enriched into the carbon fraction during the separation process.

The carrier of molybdenium and vanadium has not been identified. Apparently vanadium, whose abundance in the carbon fraction is the same as in the schist proper, is partly incorporated either in the microscopic silicate inclusions in the graphite grains or in the original clay fraction of the schist. It is not possible to prevent the latter from accompanying the carbon fraction in the separation process of a fine-grained schist rich in graphite. However, part of the vanadium is obviously bound in the carbon matter proper, as the observations on younger formations indicate.

Due to the lack of sufficient information concerning the trace element abundances in Precambrian schists formed under different conditions and their fractions, it is only possible at this stage to compare them with younger formations of known origin. Although studies on the latter are at a preliminary stage, it is interesting to trotice the remarkable abundance of molybdenium and vanadium in the studied Precambrian schists and their carbon fractions.

In a preliminary study, Degens et al (1957) have reported the relative enrichment of vanadium in organic fractions separated from marine Pennsylvanian shales.

\section{Mode of occurrence and isotopic constitution of carbon}

Carbonaceous matter occurs as graphite, with an average content of about $5.0 \%$. X-ray examinations showed that the degree of graphitisation of the carbon material was quite high. According to microscopic examinations, it is possible that schungite with a lower degree of graphitisation may occur locally in the less metamorphosed parts of the region. The graphite occurs as finegrained flakes, parallel to the schistosity, rc- 
maining as a helicitic parallel texture in the growing porphyroblasts during recrystallisation. The graphite grains vary in size, according to the grade of metamorphism, from 0.001 to $0.3 \mathrm{~mm}$. The older sulphide generation is usually free from graphite inclusions which occur abundantly in the younger generation. The graphite itself is free from inclusions, but it contains fine-grained silicates sporadically.

Since some authors hold the opinion that the isotopic constitution of carbon has a bearing on the study of the depositional environment of the carbonaceous formations, mention can be made of some preliminary investigations carried out in the Outokumpu region. T. C. Hoering (personal communication to Dr. O. Kouvo) of the Carnegie Institution of Washington, has made an isotopic determination from a graphite in a black schist of the Outokumpu mine. According to the determination

$$
\triangle C^{13}=-24.6
$$

Dr. W. U. Ault of the Lamont Observatory determined the isotopic constitution of carbon from graphite pebbles in Karelian quartzite, Outokumpu. Dr. O. Kouvo kindly placed the data at the disposal of the present author. The isotopic constitution varies from $\triangle C^{13}=$ -18.8 to -21.7 . The results are expressed in »per millage» units, as follows:

$$
\Delta \mathrm{C}^{13}=\frac{\left(\mathrm{C}^{13} / \mathrm{C}^{12}\right)-\left(\mathrm{C}^{13} / \mathrm{C}^{12}\right) \text { standard }}{\left(\mathrm{C}^{13} / \mathrm{C}^{12}\right) \text { standard }} \times 1000
$$

where the standard used was Solenhofen limestone, NBS isotope reference standard No 20.

According to Silverman and Epstein (1958), the isotopic constitution of carbon in the above specimens would indicate a marine origin, for the carbonaceous matter.

\section{Discussion}

In this study emphasis is laid upon some elements characteristic of carbonaceous schists, upon their relationship and their distribution between the schist fractions in order to collect information concerning the depositional conditions of the Precambrian black schists. The isotopic constitution of carbon, which has a bearing on the determination of the origin of a formation, has also been used as an auxilliary aid.

Attention has been focused on the mutual relationship of the amounts of carbon and sulphides in the black schists, a subject which has recently been investigated in recent carbonaceous sediments or shales of known origin. It has been observed that the amount of sulphides is higher in a marine than in a fresh-water depositional environment. Further, the abundances of sulphidic and carbonaceous matter often vary sympathetically with each other and the irregular distribution of sulphides (pyrite in recent sediments) almost exactly parallels the distribution of organic carbon.

The Outokumpu black schists are predominantly sulphidic with a sympathetic relationship between carbon and sulphur. This also holds true for the Chattanooga and Ohio shales, which, according to Strahl (1958), have some additional features characteristic of a reducing marine environment. In this connection, mention should be made of the fundamental studies of Strakhov (1960) concerning recent carbonaceous sediments.

It appears that in the black schists of the Outokumpu region and its surroundings the abundances of carbon, vanadium and boron are clearly higher than in the other rocks of the formation. However, since carbon and vanadium concentrate in reduzate sediments of different origins, their abundances, as such, cannot be used for environmental studies. On the other hand, boron, due to its ability to become enriched mainly in marine water, is applicable to such studies.

According to Landergren (1945), the boron content of a marine sediment is directly proportional to the salinity of the water in which the sediment was deposited. The Cambrian alum shales form part of the subject of his study con- 
cerning the distribution of boron in Swedish sediments and rocks. He discovered that the boron content in the alum shales is decidedly marine (the average boron content of the 161 analyses from Gislövhammar was $0.014 \% \mathrm{~B}$ and that of the 160 analyses from Södra Sandby $0.009 \%$ B). The paleontological and stratigraphic observations of Westergård (1944) confirm the fact that the deposition of these shales took place under marine conditions.

Although the number of analysed samples from the Outokumpu region is modest, the boron content in the samples $(0.015 \%$ B) is comparable with that of the alum shales which the black schists also resemble geochemically. Further it must be pointed out that the abundance of boron in the black schists outside the area occupied by serpentinites is higher than at the periphery of the serpentinites.

The information concerning the micaceous schists, mica schists, phyllites and quartzites in the area and its surroundings is incomplete. In a few samples the boron content has been observed to vary between $0.001 \%$ and $0.008 \%$ B. The lowest boron tenors have been encountered in quartzites. The abundances are compatible with those reported by Sahama (1945) for the aluminium-rich schists in South Lapland, in which the values fluctuate from 9 to $93 \mathrm{~g} / \mathrm{t} \mathrm{B}$.

Examination of the concentration of trace elements in the fractions separated from black schists reveals that especially molybdenium, but also to some extent vanadium, occurs abundantly in the carbon fractions of the schist. This is also manifested by the high $\mathrm{Mo}$ and $\mathrm{V}_{2} \mathrm{O}_{5}$ tenors in some carbon-rich argillaceous black schists. Since, according to microscopic examination, the graphite does not contain sulphide inclusions, it is probable that vanadium and molybdenium are either partly incorported in the silicatic inclusions in the graphite or that they occur concealed in the original clay fraction. In the separation process the latter follows graphite and originates from the fine-grained graphite-rich portions of the schist. Comparison of the concentra- tions in the samples and in the fractions separated from them shows that a considerable part of the abovementioned elements belongs to the carbon fraction of the black schists. Degens et al (1957) have observed the enrichment of vanadium in the organic fraction of marine Pennsylvanian shales.

It $i_{s}$ obvious that in the older schisto and especially in those submitted to strong metamorphism, mobilisation of elements has taken place. The elements have also migrated from one fraction to another even beyond the boundaries of the original rock. All these facts must be kept in mind when studying Precambrian rocks. Moreover, the intruding plutonic rocks bring with them their own trace elements causing complications to the interpretation of the results.

Consequently, the trace element concentrations in the carboneceous schists and their fractions are to be taken only as indicative and the chief emphasis must be laid upon the carbon fraction which is known to be the most resistant portion of the schist. This is supported by observations made on many Precambrian black schists showing that the carbon-rich beds in the schists are generally finer in grain than the carbon-poor or carbon-free layers alternating with them. The occasional preservation of a varved structure is sufficient to indicate the probability of seasonal variation in the sedimentation rate. As stated by Eskola (1932), the survival of such an original sedimentary utructure indicates that carbon was a primary constituent of the sediment and had from the very beginning acted to delay recrystallisation.

The mobilisation of trace elements in the carbon-rich portion of the schist has apparently always been modest and consequently, the carbon fraction has best preserved its original composition. This is further supported by the mode of occurrence of the sulphides, which also tend to become easily mobilised in black schist. In less metamorphosed parts of the region, the sulphides (pyrite and pyrrhotite) occur in carbon- 
rich beds as elongated grains or lamellae concordant to the original bedding. No graphite inclusions have been observed in them. However, graphite inclusions are consistently found in the sulphides cutting through the bedding in more metamorphosed parts, but even then the graphite grains are free from sulphide inclusions.

The feasibility of the cobalt to nickel ratio for the environmental studies of carbonaceous shales is uncertain. The opinions of various authors differ as to its suitability for a criterion of the origin of many strata-bound ore deposits. The ratio was included in this study only to permit the comparison of the Outokumpu black schists with other contemporaneous as well as younger carbonaceous formations.

The predominance of nickel over cobalt is a characteristic feature of all of the schists in the area. The average cobalt to nickel ratio in the hydrolyzate sediments is 0.40 (Goldschmidt, 1937 b). Sahama (1945) ascertained that the ratio is 0.33 in the aluminium-rich schists in South Lapland. Lundegårdh (1946) reports that this ratio varies from 0.40 to 0.43 in the shales and bituminous schists at Västergötland, Sweden. In reduzate sediments, which are often richer in nickel, the ratio is lower. In the black schists at Outokumpu, the ratio is approximately 0.15 which is the same as that given by Marmo (1960) for the numerous sulphide and graphite schists elsewhere in Finland. For comparison it can be mentioned that in the clay muds of the Black Sea (Strakhov, 1960) the cobalt to nickel ratio has the same numerical value. In the alum shales in Sweden the ratio is still more nickel predominant and varies between 0.05 and 0.1 .

According to some preliminary determinations Karelian quarzites and black schists contain carbon whose $\mathrm{C}^{13} / \mathrm{C}^{12}$ ratio fluctuates from $\triangle \mathrm{C}^{13}=$ - 18.8 to - 24.6. According to Silverman and Epstein (1958), this isotopic constitution of carbon in petroleum and organic extracts indicates a marine origin for the carbonaceous matter. Since the usage of the $\mathrm{C}^{13} / \mathrm{C}^{12}$ ratio as a salinity indicator is questionable even in connection with the younger formations, it is premature to apply it to the Precambrian formations.

The mode of occurrence and the stratigraphy of the black schists in the Outokumpu region, described earlier by the present author (Peltola, 1960), indicates that the original depositional conditions were marine. The close connection between the black schist intercalates and the extensive mica schist and phyllite formations in the area indicate a common depositional environment for them which belongs as a part to the Karelian geosynclinal formation.

Several geochemical features discussed in this paper support the above view. It is well known that both boron and sulphur are elements of the marine chemofacies and are strongly concentrated into the oceans. The information concerning the applicability of the other trace elements dealt with in this study, their mutual relationship as well as the isotopic constitution of carbon, to the Precambrian sediments is still insufficient. The mutual comparison of carbonaceous formations of Precambrian age with a continental mode of occurrence and stratigraphy, would contribute to the study of the depositional environment.

Acknowledgements - The author is indebted to Professor P. Haapala for permission to use the material collected from the Outokumpu area and to publish this paper. I also wish to thank Professor V. Marmo, Director of the Geological Survey of Finland and Professor A. Mikkola for kindly reading the manuscript and giving valuable criticism and advice. I express my appreciation to Dr. Veikko Vähätalo and Dr. T. A. Häkli for making available the laboratory facilities of the Exploration Department of the Outokumpu Company. Special thanks are addressed to Dr. Olavi Kouvo for the isotope determinations performed at the Lamont Observatory and the Carnegie Institution, which he kindly placed at the author's disposal, to Mr. Lasse Kosomaa for making several analyses and to Mrs. Gillian Häkli for translating the manuscript into English. 


\section{REFERENCES}

Degens, E. T., Williams, E. G. and Keith, M. L. (1957) Environmental studies of carboniferous sediments. Pt. I: Geochemical criteria for differentiating marine and fresh-water shales, Bull. Amer. Assoc. Petrol. Geol., vol. 41, p. 2427.

- Keith, M. L., Williams, E. G. and Kanehiro, Y. (1959) Environmental study of some recent sediments from Hawaii. J. Geol., p. .

Eskola, Pentti (1932) Conditions during the earliest geological times as indicated by the Archaean rocks. Ann. Acad. Sci. Fennicae, Ser. A, 36, No. 4.

Goldschmidt, V. M. (1937a) The principles of distribution of chemical elements in minerals and rocks. J. Chem. Soc. p. 655.

- (1937b) Geochemische Verteilungsgesetze der Elemente. IX. Die Mengenverhältnisse der Elemente und der Atom Arten. Skrifter Norske Videnskaps-Akad. Oslo, I. Mat.-naturv. Klasse, No. 4.

- (1954) Geochemistry, Oxford.

HaApala, PaAvo (1936). On serpentine rocks in Northern Karelia. Bull. Comm. géol. Finlande 114.

Hegemann, F. (1943). Die geochemische Bedeutung von Co und Ni im Pyrit. Z. angew. Miner., Bd. 4, p. 121.

JANDA, I. und SChroll, E. (1959) Geochemische Untersuchungen an Graphitgesteinen. Report of the twentyfirst session Norden. Part I. Geochemical cycles. 1960.

Keith, M. L. and Bystrom, A. M. (1959). Comparative analyses of marine and fresh-water shales, Penn. State Univ., Mineral Inds. Expt. Sta. Bull.

LANDER GREN, S. (1945) Contribution to the geochemistry of boron, II, The distribution of boron in some Swedish sediments, rocks and iron ores; the boron cycle in the upper lithosphere, Arkiv Kemi, Mineral. Geol. 19A. no 26.

- (1948). On the geochemistry of Swedish iron ores and associated rocks. A study on iron-ore formation. Sver. Geol. Undersök., Ser. C, No. 496.

Leutwein, F. (1951) Geochemische Untersuchungen an den Alaun und Kieselschiefern Thüringens. Arc. f. Lagerstättenforschung, H. 82.
LundegÅRH, P. H. (1946). Rock composition and development in Central Roslagen, Sweden. Arkiv Kemi, Mineral. Geol. 23 A, No. 9.

MARMo, Vladi (1960). On the sulphide and sulphidegraphite schists of Finland. Bull. Comm. géol. Finlande 190.

Murty, P. S. N., Aswathanarayana, U. and MahaDEVAN, C. (1962) Geochemistry of the siliceous black shales at Nagarjuna Sagar Damsite. Intia. Econ. Geol. 57, p. 614.

Peltola, Esko (1960). On the black schists in the Outokumpu region in Eastern Finland. Bull. Comm. géol. Finlande 192.

Sahama, Th. G. (1945) Spurenelemente der Gesteine im südlichen Finnisch-Lappland. Bull. Comm. géol. Finlande 135.

Saksela, Martiti (1957) Die Entstehung der Outokumpu-Erze im Lichte der tektonisch-metamorphen Stoffmobilisierung. N. Jb. Mineral,, Abh., Bd. 91. (Festband Schneidethöhn), p. 278.

Silverman, S. R. and Epstein, S. (1958). Carbon isotopic compositions of petroleums and other sedimentary organic materials. Bull. Amer. Assoc. Petrol. Geol. 42, p. 998.

Strahl, E. O. (1958). An investigation into the mineralogy and petrography of uranium-bearing shales: U.S. Atomic Energy Commission Raport NYO 7908.

Strakhov, N. M. et al. (1959). Ocherki geokhimii verkhnepaleozoiskikh otlozhenii gumidnogo tipa. Trudy Geol. Inst., U.S.S.R. Academy of Sciences, vol. 23. p. 223.

- (1960) Osnovy teorii litogeneza. vol. II. Moscow, (Academy of Sciences). p. 574.

WAMpleR, J. M. (1963). An isotopic study of lead in sedimentary pyrite. Ph. D. Thesis. Columbia University.

WestergArdh, A. H. (1944). Borrningar genom alunskifferlagret. Sver. Geol. Undersök. Ser. C. No's 459, 463.

Manuscript received, January 12, 1968 